\title{
ANALISIS UKURAN PERUSAHAAN DAN PERTUMBUHAN ASET TERHADAP STRUKTUR MODAL PERBANKAN UMUM PEMERINTAH DI BURSA EFEK INDONESIA
}

\author{
Oleh: \\ Emma Lilianti \\ Fakultas Ekonomi Universitas PGRI \\ Jalan Jenderal Ahmad Yani Lorong Gotong Royong Palembang
}

\begin{abstract}
ABSTRACK
This study aims to determine the effect of firms and asset growth on capital structure government general banking in Indonesia Stock Exchange. The problem in this research how to influence firm size and asset growth on capital structure government general banking in BEI? Data analysis, autocorrelation, multicolinearity and heterocedasticity test. The population is the entire company government general banking in BEI as many as 4 companies, with the selected sample of 4 companies through the sampling census. The results showed firm size and asset growth have influence on capital structure government general banking in Indonesia Stock Exchange (BEI).
\end{abstract}

\section{Keyword: Firm Size, Asset Growth, Capital Structure}

\begin{abstract}
ABSTRAK
Penelitian ini bertujuan untuk mengetahui pengaruh ukuran perusahaan dan pertumbuhan aset terhadap struktur modal perbankan umum pemerintah di Bursa Efek Indonesia. Permasalahan dalam penelitian ini bagaimana pengaruh ukuran perusahaan dan pertumbuhan aset terhadap struktur modal perbankan umum pemerintah di BEI? Model analisis data dengan multiple regresion melalui uji asumsi klasik yaitu uji normalitas data, autokorelasi, multikolinearitas dan uji heterokedastisitas. Populasi yaitu seluruh perusahaan perbankan umum pemerintah di BEI sebanyak 4 perusahaan, dengan sampel terpilih sebanyak 4 perusahaan melalui sensussampling. Hasil penelitian menunjukkan bahwa ukuran perusahaan dan pertumbuhan aset mempunyai pengaruh terhadap struktur modal perbankan umum pemerintah di Bursa Efek Indonesia (BEI).
\end{abstract}

\section{PENDAHULUAN}

Keberadaan sebuah perusahaan tidak hanya melakukan kegiataan yang sifatnya individual. Perusahaan perlu terus mengembangkan bisnisnya dari segi jenis produk dan besarnya skala perusahaan. Untuk itu perusahaanharus mampu bersaing dalam dunia usaha,misalnya dengan membuat inovasi barupadaproduknyasehingga meningkatkan tingkat penjualan. Perusahaan perlu melakukan perluasan usaha, meningkatkan kualitas 
sumber daya manusia, dan lainnya. Untuk melakukan semua itu dibutuhkan dana yang sangat besar. Pemenuhan kebutuhan dana dapat dilakukan dengan pendanaan internal maupun eksternal. Sumber dana internal, yaitu sumber dana yang dibentuk atau dihasilkan sendiri di dalam perusahaan, misalnya dana yang berasal dari keuntungan yang tidak dibagikan atau laba yang ditahan didalam perusahaan. Makin besar dana intern yang berasal dari laba ditahan akan semakin memperkuat posisi keuangan perusahaan dalam menghadapi kesulitan keuangan diwaktu-waktu mendatang. Laba ditahan ini dapat digunakan oleh perusahaan sebagai cadangan untuk menghadapi kerugian yang timbul dimasa datang, untuk melunasi hutang perusahaan, untuk menambah modal kerja atau pun untuk ekspansi perusahaan di masa datang.

Selain sumber dana dari internal, sumber dana yang lain adalah sumber eksternal, yaitu sumber dana yang berasal dari tambahan penyertaan modal pemilik atau penerbitan saham baru, penjualan obligasi, dan kredit dari bank. Penetapan sumber dana dianggap penting karena masing-masing sumber dana tersebut memiliki tingkat risiko yang berbeda-beda. Untuk itu manajer keuangan diharapkan mampu menerapkan pemilihan alternatif sumber dana yang paling tepat. Dalam hal ini, perusahaan perlu mempertimbangkan apakah dananya dipenuhi dari modal sendiri, hutang, atau kombinasi keduanya. Penggunaan dana yang berasal dari hutang maupun ekuitas akan membantu perusahaan dalam pengembangan perusahaan.

Bank merupakan lembaga perantara keuangan dimana rata-rata orang sering berinteraksi,Mishkin (2012:9). Salah satu hal yang penting yang dihadapi manajer keuangan adalah bagaimana seharusnya perusahaan mendapatkan dana untuk aktiva, apakah meminjam dengan menggunakanhutang atau menjual saham, Atmajaya (2014 :8). Bank juga merupakan pengumpul dana dan penyalur kredit berarti bank dalam operasinya mengumpulkan dana kepada SSU dan menyalurkan kredit kepada DSU, Hasibuan (2013:2).

Tuntutan terhadap perusahaan/industri sektor perbankan semakin besar dan luas, perusahaan/perbankan diharapkan tidak hanya mementingkan kepentingan manajemen dan pemilik modal (investor dan kreditor) tetapi juga karyawan, konsumen serta masyarakat. Perusahaan mempunyai tanggung jawab sosial terhadap pihak-pihak di luar manajemen dan pemilik modal. Terkadang perusahaan melalaikannya dengan alasan 
bahwa mereka tidak memberikan kontribusi terhadap kelangsungan hidup perusahaan. Bank adalah pengumpul dana dan penyalur kredit berarti bank dalam operasinyamengumpulkan dana kepada SSU dan menyalurkan kredit kepada DSU, Hasibuan (2012:2).

Penelitian Seftianne dan R. Handayani berjudul faktor-faktor yang mempengaruh istruktur modal pada perusahaan publik sector manufaktur menemukan bahwa ukuran perusahaan dan pertumbuhan perusahaan berpengaruh signifikan terhadap faktor modal. Yovin, D. dkk. menyatakan pertumbuhan aset mempengaruhi Struktur Modalpada Perusahaan Foodsand Beverages yang Terdaftar di Bursa Efek Indonesia, sedangkan ukuran perusahaan tidak berpengaruh signifikan. Selanjutnya penelitian Manopo dkk mengemukakan ukuran perusahaan dan pertumbuhan aset mempengaruhi Struktur Modal Perbankan yang Go Publik di BEI. Berdasarkan latar belakang penelitian di atas, rumusan masalah dalam penelitian adalah bagaimana pengaruh ukuran perusahaan dan pertumbuhan aset terhadap struktur modal Bank Umum Pemerintah di Bursa Efek Indonesia?

\section{KAJIAN TEORITIS}

\section{Pengertian Struktur Modal}

Copeland dan Weston (2010) mengungkapkan keputusan untuk memilih sumber pembiayaan merupakan keputusan bidang keuangan yang paling penting bagi perusahaan. Sumber pembiayaanatau sumber pedanaan suatu perusahaan dapat dilihat di sisi pasiva dari neraca perusahaan sedangkanpenggunaan dana dapat di lihat pada sisi aktiva dari neraca perusahaan. Aset yang dimilikiperusahaan menunjukkan penggunaan bersih dari dana sedangkan hutang dan modal sendirimencerminkan sumber dananya (Husnan, 2011). Struktur modal adalah komposisi ekuitas dan pinjaman dalam pembiayaan proyek. Komposisiekuitas dan pembiayaan proyek akan menghasilkan biaya modal rata-rata yang berbeda apabilakomposisinya berbeda. Untuk itu, pembahasan tentang struktru modal mnenjadi penting karena tidaksaja menyangkut biaya modal yang harus dibayar kembali oleh investor, tetapi menjadi barometerkeuntungan. Pembahasan mengenai teori struktur modal ini banyak dilakukan oleh Modiglani danMiller dalam kaitan rencana titik optmila dari komposisi ekuitas dan pinjaman yang akan 
menghasilkan keuntungan kamsimal. Keuntungan maksimal disini diasumsikan pada tingkat IRR konstan, Yusgiantoro (2010: 145)

\section{Faktor-Faktor yang Mempengaruhi Struktur Modal}

Copeland dan Weston (2010) mengungkapkan penentuan struktur modal perlu mempertimbangan hal-hal yaitu, tujuan perusahaan, tingkat leverage, kemampuan dana intern, pemusatan pemilikan dan pengendalian suara, batas kredit, besarnya perusahaan, pertumbuhan aset perusahaan, stabilitasearnings, biaya modal sendiri, biaya hutang, tarif pajak, perkiraan tingkat inflasi dan kemampuan dana. Faktor-faktor yang berpengaruh dalam pengambilan keputusan struktur modal adalah:

1. Stabilitas penjualan. Perusahaan dengan penjualan yang relatif stabil dapat lebih aman memperoleh lebih banyak pinjaman dan menanggung beban tetap yang lebih tinggi dibandingkan dengan perusahaan yang penjualannnya tidak stabil.

2. Struktur aset. Perusahaan yang asetnya sesuai untuk dijadikan jaminan kredit cenderung lebih banyak menggunakan banyak utang. Aset multiguna yang dapat digunakan oleh banyak perusahaan merupakan jaminan yang baik, sedangkan aset yang hanya dapat digunakan untuk tujuan tertentu tidak begitu baik untuk dijadikan jaminan.

3. Leverage operasi. Jika hal-hal lain tetap sama, perusahaan dengan leverage operasi yang lebih kecil cenderung lebih mampu untuk memperbesar leverage keuangan karena ia akan mempunyai risiko bisnis yang lebih kecil.

4. Tingkat pertumbuhan. Jika hal-hal lain tetap sama, perusahaan yang tumbuh dengan pesat harus lebih banyak menggunakan modal eksternal. Lebih jauh lagi, biaya pengambangan untuk penjualan saham biasa jauh lebih besar daripada biaya untuk penerbitan surat utang, yang mendorong perusahaan untuk lebih banyak mengandalkan utang. Namun, pada saat yang sama perusahaan yang tumbuh dengan pesat sering menghadapi ketidakpastian yang lebih besar, yang cenderung mengurangi keinginannya untuk menggunakan utang.

5. Profitabilitas. Seringkali pengamatan menunjukan bahwa perusahaan dengan tingkat pengembalian yang tinggi atas investasi menggunakan utang yang relatif kecil.

6. Pajak. Bunga merupakan beban yang dapat dikurangkan untuk tujuan perpajakan, dan pengurangan tersebut sangat bernilai bagi perusahaanyang terkena tarif pajak yang tinggi. Karena itu makin tinggi tarif pajak perusahaan, makin besar manfaat penggunaan utang.

7. Pengendalian. Pengaruh utang lawan saham terhadap posisi pengendalian manajemen dapat mempengaruhi struktur modal. Apabila manajemen saat ini mempunyai hak untuk mengendalikan perusaahaan tetapi sama sekali tidak diperkenankan untuk membeli saham tambahan, mereka mungkin akan memilih utang untuk pembiayaan baru. Di lain pihak, manajemen memutuskan untuk menggunakan ekuitas jika kondisi keuangan perusahaan sangat lemah sehingga penggunaan utang dapat membawa perusahaan pada risiko kebangkrutan, karena jika perusahaan jatuh bangkrut, para 
manajer tersebut akan kehilangan pekerjaan. Tetapi, jika utangnya terlalu kecil mereka akan menghadapi risiko pengambilalihan.

\section{Teori Struktur Modal}

Agency Theory, teoriini dikemukakan oleh Michael C. Jensen dan William H. Meckling pada tahun 1976. Jensen dan William (dalam Horne dan Wachowicz, 2007:482) berpendapat bahwa manajemen merupakan agen dari pemegang saham, sebagai milik perusahaan. Para pemegang saham berharap agen bertindak atas kepentingan mereka sehingga mendelegasikan wewenang kepada agen. Telah diketahui bahwa para manajer mungkin memiliki tujuan pribadi yang bersaing dengan tujuan memaksimalkan kekayaan pemegang saham. Manajer diberi kekuasaan oleh para pemilik perusahaan, yaitu pemegang saham untuk membuat keputusan dimana hal ini menciptakan potensi konflik kepentingan yang dikenal sebagai teoriagensi (Brigham dan Houston, 2011:26). Menurut pendekatan ini, struktur modal disusun sedemikian rupa untuk mengurangi konflik antar berbagai kelompok kepentingan (Mamduh, 2015:91). Penyebab konflik antara manajer dengan pemegang saham berkaitan dengan aktivitas pencarian dana dan bagaimana dana tersebut diinvestasikan. Menurut teori ini, semakin tidak stabil pendapatan perusahaan dan semakin besarnya profitabilitas mengalami kebangkrutan, maka masalah yang berhubungan dengan hutang semakin besar.

Trade-off Theory, teori ini mengasumsikan bahwa struktur modal perusahaan merupakan hasil trade-off dari keuntungan pajak dengan menggunakan hutang dengan biaya yang akan timbul sebagai akibat penggunaan hutang tersebut (Sartono,2010). Esensitrade- off theory dalam struktur modal adalah menyeimbangkan manfaat dan pengorbanan yang timbul sebagai akibat penggunaan hutang. Sejauh manfaat lebih besar, tambahan hutang masih diperkenankan. Apabila pengorbanan karena penggunaan hutang sudah lebih besar, maka tambahan hutang sudah tidak diperbolehkan. Teori ini menjelaskan sebuah perusahaan yang struktur modalnya tanpa menggunakan hutang dengan keseluruhan menggunakan hutang adalah perusahaan yang dalam keadaan buruk. Perusahaan tanpa menggunakan hutang dalam modalnya akan membayar pajak yang lebih besar daripada perusahaan yang menggunakan hutang. Hal tersebut akan mempengaruhi nilai perusahaan. Nilai perusahaan dengan menggunakan hutang akan lebih besar dibanding perusahaan tanpa menyertakan hutang dalam modalnya. 
Perusahaan dengan modal keseluruhan hutang dikatakan buruk karena dalam setiap hutang terdapat bunga hutang yang dibayarnya. Dengan keseluruhan hutang dalam modal perusahaan, dalam setiap keuntungan perusahaan tersebut akan menggunakan labanya untuk membayar bunga. Tentu keadaan tersebut tidak menguntungkan bagi sebuah perusahaan. Perusahaan dapat melakukan perhitungan mengenai struktur modal optimal dengan mempertimbangkan peningkatan nilai perusahaan dan biaya yang akan muncul.

Pecking Order Theory, teori ini disebut sebagai pecking order karena teori ini menjelaskan mengapa perusahaan akan menentukan hierarki sumber dana yang paling disukai. Secara ringkas teori tersebut menyatakan bahwa (Brealey dan Myers dalam Husnan, (2011:3): (a) Perusahaan menyukai internal financing (pendanaan dari hasil operasi perusahaan), (b) Perusahaan mencoba menyesuaikan rasio pembagian dividen yang ditargetkan, dengan berusaha menghindari perubahan pembayaran dividen secara drastis, (c) Kebijakan dividen yang relatif segan untuk diubah, disertai dengan fluktuasi profitabilitas dan kesempatan investasi yang tidak bias diduga, mengakibatkan bahwa dana untuk investasi, meskipun pada kesempatan yang lain, mungkin kurang. Apabila dana hasil operasi kurang dari kebutuhan investasi, maka perusahaan akan mengurangi saldo kas untuk menjual sekuritas yang dimiliki, dan (d) Apabila pendanaan dari luar (eksternal financing) diperlukan, maka perusahaan akan menerbitkan sekuritas yang paling aman terlebih dahulu yaitu dimulai dengan penerbitan obligasi, kemudian diikuti oleh sekuritas, baru akhirnya apabila masih belum mencukupi, saham baru diterbitkan.

AsymmetricInformation Theory atau ketidaksamaan informasi menurut Brigham dan Houston (2011:35), adalah situasi dimana manajer memiliki informasi yang berbeda (yang lebih baik) mengenai prospek perusahaan dari pada yang dimiliki investor. Keadaan ini memungkinkan para manajer menggunakan informasi yang diketahuinya untuk mengambil keputusan, khususnya keputusan pendanaan perusahaan. Dalam asymmetric information theory, menjelaskan bahwa ukuran perusahaan berpengaruh terhadap lebih tertutup atau terbukanya perusahaan untuk membagi informasi kepada pihak luar. Perusahaan kecil menganggap bahwa membagi informasi kepada pihak pemberi pinjaman atau modal membutuhkan biaya yang besar. Hal ini 
menghambat penggunaan pendana an eksternal dan meningkatkan kecenderungan bagi perusahaan kecil untuk menggunakan modal perusahaan.

SignalingTheory, menurut Brigham dan Houston (2011:39), signal atau isyarat adalah suatu tindakan yang diambil manajemen perusahaan yang memberi petunjuk bagi investor tentang bagaimana manajemen memandang prospek perusahaan. Perusahaan dengan prospek yang menguntungkan akan mencoba menghindari penjualan saham, termasuk penggunaan hutang yang melebihi target struktur modal yang normal. Perusahaan dengan prospek yang kurang menguntungkan akan cenderung untuk menjual sahamnya. Pengumuman emisi saham oleh suatu perusahaan umumnya merupakan suatu isyarat (signal) bahwa manajemen memandang prospek perusahaan tersebut suram. Apabila suatu perusahaan menawarkan penjualan saham baru, lebih sering dari biasanya, maka harga saham akan menurun, karena menerbitkan saham baru berarti memberi isyarat negative yang kemudian dapat menekan harga saham sekalipun prospek perusahaan cerah.

\section{Komponen Struktur Modal}

Komponen yang menjadi penyusunan dalam komposisistrukturmodalterdiridari hutang jangka panjang, saham biasa, saham preferen dan laba ditahan. Liabilitas tidak lancer adalah kewajiban yang jangka waktunya adalah panjang umumnya lebih dari sepuluh tahun (Sartono,2010:238). Hutang jangka panjang ini pada umumnya digunakan untuk membiayai perluasan perusahaan (ekspansi) atau modernisasi dari perusahaan. Komponen-komponen hutang jangka panjang ini terdiri dari: (a) Hutang hipotik adalah bentuk hutang jangka panjang yang dijamind engan aktiva tidak bergerak (tanah dan bangunan), (b) Obligasi adalah sertifikat yang menunjukan pengakuan bahwa perusahaan meminjam uang dan menyetujui untuk membayarnya kembali dalam jangka waktu tertentu. Pelunasan atau pembayaran kembali obligasi dapat diambil dari penyusutan aktiva tetap yang dibelanjai dengan pinjaman obligasi tersebut dan dari keuntungan.

\section{Kerangka Pemikiran}

Berdasarkan rumusan masalah di atas, maka kerangka pemikiran dalam penelitian: 


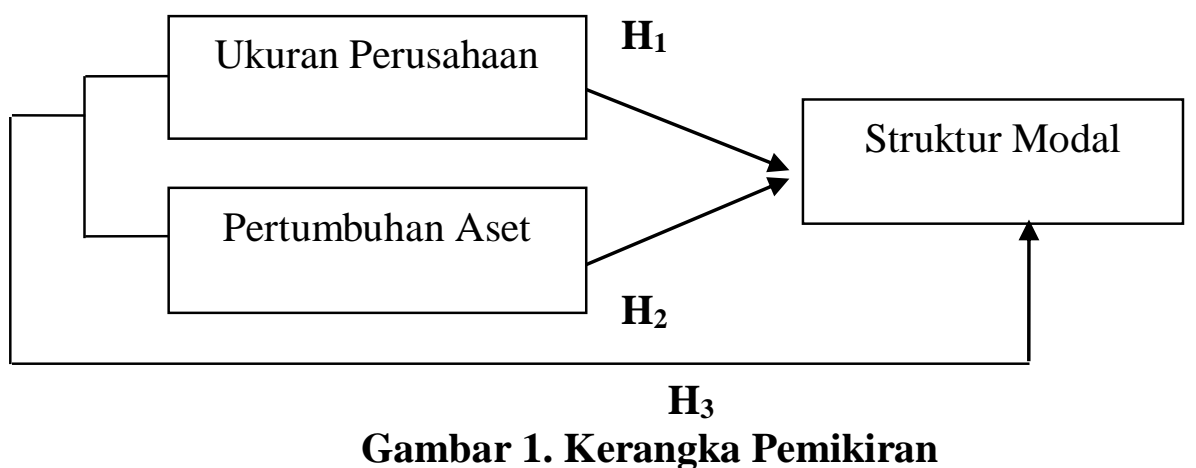

\section{Hipotesis Penelitian}

Berdasarkan kerangka pemikiran diatas, peneliti merumuskan hipotesis sebagai berikut :

$\mathrm{H}_{1}$ : Ukuran perusahaan berpengaruh positif terhadap struktur modal pada Bank Umum Pemerintah di BEI.

$\mathrm{H}_{2}$ :Pertumbuhan Asetberpengaruh positif terhadap struktur modal pada Bank Umum Pemerintah di BEI.

$\mathrm{H}_{3}$ : Ukuran perusahaan dan pertumbuhan aset terhadap struktur modal pada Bank Umum Pemerintah di BEI.

\section{METODE PENELITIAN}

Definisi Operasional

\section{Tabel 1. Definisi Operasional Variabel}

\begin{tabular}{|c|c|c|c|}
\hline Variabel & Definisi & Indikator & Proksi \\
\hline $\begin{array}{l}\text { Ukuran } \\
\text { Perusahaan } \\
\mathrm{X}_{1}\end{array}$ & $\begin{array}{l}\text { Ukuran atau besarnya asset yang dimiliki } \\
\text { perusahaan.Variabel ukuran perusahaan } \\
\text { dalam penelitian ini diukur dengan } \\
\text { menggunakan nilai logaritma natural }(L n) \text { dari } \\
\text { total aset }\end{array}$ & $\begin{array}{l}\text { 1. Aset lancar } \\
\text { 2. Aset tetap }\end{array}$ & LOG Total Aset \\
\hline $\begin{array}{c}\text { Pertumbuha } \\
\text { n Aset } \\
\mathrm{X}_{2}\end{array}$ & $\begin{array}{l}\text { selisih antara jumlah aset periode ini dengan } \\
\text { periode sebelumnya dibandingkan dengan } \\
\text { aset periode sebelumnya }\end{array}$ & $\begin{array}{ll}\text { 1. } & \text { Aset } t \\
\text { 2. } & \text { Aset } t-1\end{array}$ & $\mathrm{G}=\frac{\text { Aset } \mathrm{t}-\text { Aset } \mathrm{t}-1}{\text { Aset } \mathrm{t}-1}$ \\
\hline $\begin{array}{l}\text { Struktur } \\
\text { Modal } \\
(Y)\end{array}$ & $\begin{array}{l}\text { Rasio ini menunjukan perbandingan antara } \\
\text { jumlah liabilitas tidak lancar dan liabilitas } \\
\text { lancar yang diberikan para kreditur terhadap } \\
\text { jumlahmodalsendiriyang diberikanolehpemilik } \\
\text { perusahaan }\end{array}$ & $\begin{array}{l}\text { 1. Liabilitas } \\
\text { Lancar } \\
\text { 2. Liabilitas tidak } \\
\text { Lancar } \\
\text { 3. Ekuitas }\end{array}$ & DER $=\frac{\text { Total Liabilitas }}{\text { Total Ekuitas }}$ \\
\hline
\end{tabular}

Sumber: Copeland dan Weston (2010)

\section{Populasi dan Sampel}

Populasi dalam penelitian ini adalah 4 perusahaan sektor perbankan yang terdapat di BEI. Teknik Sampel yang digunakan sampling jenuh/sensus adalah teknik penentuan 
sampel bila semua anggota populasi digunakan sebagai sampel. Hal ini sering dilakukan bila jumlah populasi relatif kecil, kurang dari 30 sampel.

Tabel 2. Sampel Penelitian

\begin{tabular}{ccl}
\hline No & Kode & \multicolumn{1}{c}{ Nama Emiten } \\
\hline 1 & BBTN & PT. Bank Tabungan Negara (persero) Tbk \\
2 & BBRI & Pt. Bank Rakyat Indonesia (persero) Tbk \\
3 & BBNI & PT. Bank Negara Indonesia (Persero) Tbk \\
4 & BMRI & PT. Bank Mandiri (Persero) Tbk
\end{tabular}

Sumber: http://idx.co.id

\section{HASIL PENELITIAN DAN PEMBAHASAN Hasil Penelitian}

Hasil perhitungan ukuran perusahaan, pertumbuhan aset dan struktur modal perbankan umum pemerintah tahun 2011 s.d 2015 adalah sebagai berikut:

\section{Tabel.3.}

Perhitungan size perusahaan,Growth aset dan struktur modal perbankan umum pemerintah di BEI Tahun 2011 s.d 2015

\begin{tabular}{ccccc} 
Bank & Tahun & Log Aset & Pertumbuhan Aset & Struktur Modal \\
\hline BNI & 2011 & 8,476 & 0,030 & 6,90 \\
& 2012 & 8,523 & 0,115 & 6,66 \\
& 2013 & 8,587 & 0,161 & 7,11 \\
& 2014 & 8,620 & 0,077 & 5,59 \\
BRI & 2015 & 8,634 & 0,035 & 5,81 \\
& 2011 & 8,813 & 0,140 & 8,43 \\
& 2012 & 8,741 & 0,152 & 7,50 \\
& 2013 & 8,797 & 0,136 & 6,89 \\
BTN & 2014 & 8,904 & 0,281 & 7,21 \\
& 2015 & 8,888 & 0,036 & 6,57 \\
& 2011 & 7,950 & 1,044 & 11,77 \\
& 2012 & 8,048 & 1,254 & 9,87 \\
& 2013 & 8,118 & 1,274 & 10,35 \\
& 2014 & 8,160 & 1,102 & 10,84 \\
Mandiri & 2015 & 8,193 & 1,079 & 11,22 \\
& 2011 & 8,742 & 0,106 & 7,81 \\
& 2012 & 8,803 & 0,152 & 7,31 \\
& 2013 & 8,865 & 0,153 & 7,26 \\
& 2014 & 8,932 & 0,166 & 7,16 \\
& 2015 & 8,961 & 0,069 & 6,90 \\
\hline \multirow{6}{*}{ Sum } & & &
\end{tabular}

Sumber: www.idx.co.id, diolah Tahun 2017 


\section{Hasil Uji Asumsi Klasik}

Pengujian jenis ini digunakan untuk menguji asumsi, apakah model regresi yang digunakan dalam penelitian ini layak atau tidak, uji asumsi klasik terdiri atas:

\section{Hasil Uji Normalitas Data}

Uji normalitas bertujuan untuk menguji apakah dalam model regresi, variabel pengganggu atau residual memiliki distribusi normal atau tidak. Uji normalitas data dilakukan dengan uji One-Sample Kolmogrov-Smirno Test dengan bantuan software SPSS 22. Berikut hasil dari pengujian normalitas dapat dilihat pada tabel dibawah ini:

\section{Tabel.4}

\section{Hasil Uji Normalitas Data}

\begin{tabular}{llrrr}
\hline & & Size.Firm & Growth.Aset & \multicolumn{1}{c}{ DER } \\
\hline $\mathrm{N}$ & & 20 & 20 & 20 \\
Normal Parametersa,b & Mean & 8,5878 &, 3781 & 7,9580 \\
& Std. Deviation &, 32366 &, 46361 & 1,82590 \\
Most Extreme Differences & Absolute &, 182 &, 376 &, 249 \\
& Positive &, 139 &, 376 &, 249 \\
& Negative &,- 182 &,- 226 &,- 124 \\
Kolmogorov-Smirnov Z & &, 814 & 1,683 & 1,114 \\
Asymp. Sig. (2-tailed) & &, 521 &, 007 &, 167 \\
\hline
\end{tabular}

Sumber: Hasil pengolahan data dengan SPSS versi 22, Tahun 2017

Dari tabel 4 menunjukkan bahwa nilai Asymp Sig. (2-tailed) dari ukuran perusahaan sebesar 0,521, pertumbuhan aset sebesar 0,007, dan struktur modal sebesar 0,167. Nilai Asymp Sig. (2-tailed) tersebut > 0,05, maka dapat diambil kesimpulan bahwa variabel pertumbuhan perusahaan dan ukuran perusahaan serta struktur modal secara statistik telah terdistribusi secara normal dan layak digunakan sebagai data untuk penelitian.

\section{Hasil Uji Autokorelasi}

Uji autokorelasi bertujuan untuk menguji apakah dalam suatu model regresi linear ada korelasi antara kesalahan pengganggu pada periode t-1 (sebelumnya). Pengujian ini dilakukan dengan uji Durbin-watson testdengan bantuan SPSS 22. Berikut hasil pengujian dapat dilihat pada tabel dibawah ini: 


\section{Tabel.5}

\section{Hasil Uji Autokorelasi}

\begin{tabular}{|c|c|c|c|c|c|}
\hline & & & Adjusted R & Std. Error of the & \\
\hline Model & $\mathrm{R}$ & R Square & Square & Estimate & Durbin-Watson \\
\hline 1 &, $915^{a}$ & ,837 & ,817 & ,78052 & 1,935 \\
\hline
\end{tabular}

Dari tabel 5 tertera nilai DW sebesar 1,935 dengan demikian nilai DW berada antara (1,55 sampai 2,46), maka dapat disimpulkan bahwa tidak terjadi masalah autokorelasi dalam penelitian ini.

\section{Hasil Uji Multikolinearitas}

Pengujian ini dilakukan untuk menguji ada tidaknya kolerasi antara sesama variabel independen yang ada dalam model regresi dengan melihat tolerance dan Variance inflation Factor (VIF). Nilai tolerance yang rendah sama dengan VIF yang tinggi (karena $\mathrm{VIF}=1 /$ tolerance $)$. Berikut hasil pengujian dapat dilihat pada tabel dibawah ini:

\section{Tabel 6.}

\section{Hasil Uji Multikolinearitas}

\begin{tabular}{llll}
\hline & & \multicolumn{2}{c}{ Collinearity Statistics } \\
\multicolumn{2}{c}{ Model } & Tolerance & \multicolumn{1}{c}{ VIF } \\
\hline 1 & (Constant) & & \\
& Size.firm &, 238 & 4,193 \\
& Growth.aset &, 238 & 4,193 \\
\hline
\end{tabular}

Sumber: Hasil pengolahan data dengan SPSS versi 22

Dari tabel 5 dapat dilihat bahwa nilai VIF dari model analisis pada penelitian ini $<10$ dan nilai tolerance $>0,10$. Nilai VIF ukuran perusahaan dan pertumbuhan aset sebesar 4.193 dan nilai tolerance ukuran perusahaan dan pertumbuhan asetsebesar0,238, maka dapat disimpulkan bahwa tidak terjadi multikolonieritas pada penelitian ini.

\section{Hasil Uji Model Analisis}

Regresi linier berganda, yaitu metode statistik yang digunakan untuk mengetahui pengaruh variabel terikat terhadap variabel bebas, dapat dilihat pada tabel berikut ini: 


\section{Tabel 7}

\section{Hasil Uji Regresi Linear Berganda}

\begin{tabular}{lllll}
\hline \multicolumn{2}{l}{ Model } & \multicolumn{2}{l}{ Unstandardized Coefficients } & $\begin{array}{l}\text { Standardized } \\
\text { Coefficients }\end{array}$ \\
\hline 1 & (Constant) & 6,305 & 9,993 & \\
& Size.firm &, 033 & 1,133 &, 006 \\
& Growth.aset &, 622 & 1,791 &, 320 \\
\hline
\end{tabular}

Sumber: Hasil pengolahan data dengan SPSS versi 22

Dari tabel diatas dapat disusun persamaan regresi linier berganda sebagai berikut:

$$
\mathrm{Y}=6,305+0,033 \mathrm{X}_{1}+0,622 \mathrm{X}_{2}
$$

Berdasarkan model regresi ini terlihat bahwa :

a. Konstanta sebesar 6,305 menunjukan bahwa jika variabel independen (ukuran perusahaan dan pertumbuhan aset) dianggap konstan (bernilai nol) maka struktur modal akan tetap ada sebesar 6,305.

b. Koefisien regresi adalah sebesar 0,033 artinya apabila ukuran perusahaan mengalami kenaikan sebesar satu satuan maka akan menyebabkan struktur modal meningkat sebesar 0,033 satuan.

c. Koefisien regresi pertumbuhan aset adalah sebesar 0,622 artinya apabila pertumbuhan aset mengalami kenaikan sebesar satu satuan maka akan menyebabkan struktur modal meningkat sebesar 0,622 satuan.

\section{Hasil Uji Hipotesis}

\section{a. Hasil Uji Hipotesis F}

Uji Simultan (Uji F) digunakan untuk menguji pengaruh variabel ukuran perusahaan dan pertumbuhan aset terhadap struktur modal.

\section{Tabel 8.}

\section{Hasil Uji Hipotesis F}

\begin{tabular}{lrrrrrr}
\hline Model & & Sum of Squares & Df & Mean Square & F & Sig. \\
\hline 1 & Regression & 52,988 & 2 & 26,494 & 43,489 &, $000^{\mathrm{a}}$ \\
& Residual & 10,357 & 17 &, 609 & & \\
& Total & 63,344 & 19 & & & \\
\hline
\end{tabular}

Sumber: Hasil pengolahan data dengan SPSS versi 22

Hasil uji $\mathrm{F}$ menunjukkan bahwa nilai sig $\mathrm{F}$ sebesar $0,000<\operatorname{sig} \alpha 0,05$ artinya terdapat pengaruh ukuran perusahaan dan ukuran perusahaan terhadap struktur modal perbankan umum pemerintah di BEI, artinya $\mathrm{H} 0$ ditolak. 


\section{b. Uji Koefisien Regresi (Uji t)}

Uji koefisien regresi digunakan untuk melihat tingkat signifikan masing-masing koefisien regresi.

\section{Tabel.9}

\section{Hasil Uji koefisien $t$}

\begin{tabular}{llrrr}
\multicolumn{2}{l}{ Model } & $\mathrm{t}$ & \multicolumn{2}{c}{ Sig. } \\
\hline $1 \quad$ (Constant) &, 631 & \multicolumn{2}{c}{, 536} & \\
& Size.firm & &, 029 &, 057 \\
& Growth.aset & 1,580 &, 000 \\
\hline
\end{tabular}

Sumber: Hasil pengolahan data dengan SPSS versi 22

Dari Tabel 9 variabel ukuran perusahaan menunjukkan nilai sig t sebesar $0,057<$ $\operatorname{sig} \alpha=0,05$ dan variabel pertumbuhan aset menunjukkannilaisig t sebesar $0,000 \leq \operatorname{sig} \alpha$ $=0,05$. Maka $\mathrm{H}_{0}$ ditolak dan $\mathrm{H}_{\mathrm{a}}$ diterima, artinya terdapat pengaruh ukuran perusahaan dan pertumbuhan aset secara parsial terhadap struktur modal perbankan umum pemeerintah di BEI.

\section{Pembahasan}

Hasil penelitian menunjukkan hasil bahwa secara bersama-sama dan parsial ukuran perusahaan dan pertumbuhan aset berpengaruh signifikan terhadap struktur modal perbankan umum pemerintah di BEI. Hasil temuan ini mendukung penelitian Manopo dkk. (2011) yang menyatakan bahwa ukuran perusahaan mempengaruhi secara signifikan perbankan umum pemerintah. Dalam setiap penggunaan sumber dana baik dari modal sendiri atau modal asing, pasti mempunyai biaya modal yang berbeda-beda dan tingkat risiko yang berbeda pula. Setiap perusahaan baik perusahaan besar ataupun kecil pasti akan menggunakan sumber dana yang lebih aman terlebih dahulu (pendanaan secara internal), daripada menggunakan sumber dana dari luar. Selain itu, didukung dengan kondisi ekonomi yang tidak stabil mengakibatkan setiap perusahaan memiliki kebijakan masing-masing dalam menentukan struktur modalnya. Perusahaan besar dapat dengan mudah untuk menganalisis pasar modal, akan lebih mudah tergabung dan memahami pasar modal dan efek-efek yang diperjualbelikan. Kemudahan dalam mengakses pasar modal membuktikan bahwa perusahaan memiliki fleksibilitas dan kemampuan untuk mendapatkan dana yang dibutuhkan. Semakin besar suatu perusahaan maka 
kecenderungan penggunaan dana eksternal juga akan semakin besar karena semakin besar peluang untuk melakukan ekspansi perusahaan dan peningkatan jumlah produk.

Hasil pengujian regresi menunjukkan bahwa pertumbuhann aset berpengaruhsignifikan terhadap struktur modal. Bertentangan dengan penelitian Sansoethan (2015) yang menyatakan bahwa pertumbuhan aset tidak berpengaruh terhadap struktur modal. Pengaruh positifyang ditemukan dalam penelitian ini menunjukkan berarti semakin tinggi pertumbuhan aset maka struktur modal semakin tinggi. Sebaliknya pertumbuhan asset tidak berpengaruh signifikan terhadap struktur modal, berarti bahwa perubahan peningkatan maupun penurunan suatu asset yang diperoleh perusahaan setiap waktu tidak akan mempengaruhi pihak manajemen dalam pengambilan keputusan pendanaan dalam rangka pemenuhan kebutuhan dana perusahaan. Hasil penelitian in itidak sesuai dengan pecking ordertheory yang menyatakan bahwa perusahaan dengan tingkat pertumbuhan aset yang tinggi akan melakukan ekspansi dengam cara menggunakan dana eksternal berupa hutang. Juga menurut signaling theory, perusahaan dengan tingkat pertumbuhan aset yang tinggi cenderung menggunakan tingkat hutang yang lebih besar dalam struktur modal.

\section{KESIMPULAN}

Hasil uji $\mathrm{F}$ menunjukkan bahwa nilai sig $\mathrm{F}$ sebesar $0,000<\operatorname{sig} \alpha 0,05$ artinya terdapat pengaruh ukuran perusahaan dan pertumbuhan aset terhadap struktur modal perbankan umum pemerintah di BEI. Hasil uji t menunjukkan ukuran perusahaan dengan nilai sig $\mathrm{t}$ sebesar $0,057<\operatorname{sig} \alpha=0,05$ dan variabel pertumbuhan aset menunjukkan nilai sig $\mathrm{t}$ sebesar $0,000 \leq \operatorname{sig} \alpha=0,05$. Maka $\mathrm{H}_{0}$ ditolak dan $\mathrm{H}_{\mathrm{a}}$ diterima, artinya terdapat pengaruh ukuran perusahaan dan pertumbuhan asset secara parsial terhadap struktur modal perbankan umum pemerintah di BEI.

\section{DAFTAR PUSTAKA}

Brigham, E.F. dan J.F. Houston. (2010). Fundamentals of Financial Management. 8th ed.Harcourt College Publishers. Orlando. Terjemahan H. Wibowo. 2006. Manajemen Keuangan. Edisi Kedelapan. Erlangga.Jakarta.

Copeland, Rhomas. E dan J. Fred Weston. (2011). Manajemen Keuangan. Edisi Kedelapan. Julid 2:Binarupa Aksara

Hasibuan Malayu S.P. 2007. Dasar Dasar Perbankan, Penerbit Bumi Aksara Jakarta 
Husnan, S.(2011). Manajemen Keuangan Teori dan Penerapan. Edisi Keempat. BPFE. Yogyakarta.

Mamduh, M.H.(2015).Manajemen Keuangan Internasional. BPFE. Yogyakarta.

Manopo, Fimber, Widy. (2013). Faktor-Faktor yang Mempengaruhi Struktur Modal Perbankan yang Go Publik di BEI. Jurnal EMBA Vol.1 (3) Juni 2013. Hal:653-663

Mishkin Frederic S. (2012).Ekonomi Uang, Perbankan,dan Pasar Keuangan. Indeks

Sansoethan, Kusuma Dithya. (2015) Faktor-Faktor yang Mempengaruhi Struktur Modal Pada Perusahaan Makanan dan Minuman. Jurnal Ilmu \& Riset Akuntansi Vol 5 (1) Januari 2015. Hal: 9-31

Seftianne dan R.Handayani. (2011). Faktor-faktor yangMempengaruhi Struktur Modal pada Perusahaan Publik Sektor Manufaktur. Jurnal Bisnis dan Akuntansi 13 (1): 39-56.

Sartono, Agus. (2010). Manajemen Keuangan Teori dan Aplikasi. Edisi Ke-Empat. Yogjakarta: BPFE.

Yovin, D. dan N. P.S. Suryantini. (2012). Faktor-faktor yang Berpengaruh terhadap Struktur Modal pada Perusahaan Foods and Beverages yang Terdaftar di Bursa Efek Indonesia. E-Jurnal Manajemen Universitas Udayana 1 (2) 